ECOLOGICA, Vol. 28, No 102 (2021), 158-164

https://doi.org/10.18485/ecologica.2021.28.102.3

Originalni naučni rad

UDC: [616.98:578.834]:339.562(497.11)

\title{
Uvoz robe u Srbiju tokom COVID-19 pandemije
}

\section{Import of goods in Serbia during the COVID-19 pandemic}

\author{
Ana Čučulović ${ }^{1 \star}$, Jelena Stanojković ${ }^{2}$ Rodoljub Čučulović ${ }^{3}$, Dragan Veselinović4 \\ 1,2Univerzitet u Beogradu, Institut za primenu nuklearne energije - INEP, Banatska 31b, Zemun, Srbija / \\ University of Belgrade, Institute for the Application of Nuclear Energy - INEP, Banatska 31b, Zemun, Serbia \\ 3 Univerzitet Union Nikola Tesla, Poslovni i pravni fakultet, 11000 Beograd, Srbija / \\ University of Union Nikola Tesla, Faculty of Business and Low, 11000 Belgrade, Serbia \\ ${ }^{4}$ Univerzitet u Beogradu, Fakultet za fizičku hemiju, Studentski trg 12-16, Beograd, Srbija / \\ University of Belgrade, Faculty of Physical Chemistry, Studentski trg 12-16, Belgrade, Serbia \\ ${ }^{*}$ Autor za prepisku / Corresponding author
}

Rad primljen / Received: 10.12.2020, Rad prihvaćen / Accepted: 14.05.2021.

Sažetak: Institut za primenu nuklearne energije - INEP je ovlašćeno pravno lice za poslove merenja sadržaja radionuklida u vodi za piće, životnim namirnicama, stočnoj hrani, veštačkim đubrivima, lekovima, predmetima opšte upotrebe, građevinskom materijalu, rudama, metalnim proizvodima primarnog oblika, mineralnim sirovinama, sekundarnim sirovinama i drugoj robi. U INEP-u je u prvoj polovini 2020. godine analiziran 1821 uzorak (1299 namirnica, 4 stočne hrane, 51 predmeta opšte upotrebe, 120 veštačkih đubriva i 347 ostalo), što je za $57 \%$ više u odnosu na 2019. Ovo govori u prilog tome da je stanovništvo Srbije u prvom piku COVID-19 bilo obezbeđeno robom široke potrošnje uprkos pandemiji, za razliku od mnogih zemalja u Evropi gde su zabeležene nestašice.

Ključne reči: radionuklidi, uvoz, roba široke potrošnje, Srbija, COVID-19, INEP.

\begin{abstract}
Institute for the Application of Nuclear Energy - INEP is an authorized legal entity for measuring the content of radionuclides in drinking water, food, animal feed, mineral fertilizers, medicines, general purpose items, construction material, ores, primary metal products, mineral raw materials, secondary raw materials and other goods. In the first half of 2020 in INEP were analyzed 1821samples (1299 food, 4 feed, 51 items of general use, 120 mineral fertilizers and 347 others), which is $57 \%$ more than in 2019 . This speaks in favor of the fact, that the population of Serbia in first peak of COVID-19 was provided with consumer goods despite the pandemic, unlike many countries in Europe where scarcities were recorded.
\end{abstract}

Keywords: radionuclides, import, consumer goods, Serbia, COVID-19, INEP.

${ }^{1}$ orcid.org/0000-0001-9315-4559, e-mail: anas@inep.co.rs

2orcid.org/0000-0003-3784-842X, e-mail: jelenas@inep.co.rs

${ }^{3}$ orcid.org/0000-0003-4472-0424, e-mail: rodoljub_cuculovic@yahoo.com

4orcid.org/0000-0002-7226-3833, e-mail: cuculovicana@gmail.com 


\section{UVOD / INTRODUCTION}

Korona virusi su prvi put izolovani 1962. godine. Prouzrokuju respiratorne, neurološke i enterične infekcije, bolest jetre, kod sisara, ptica i u ljudskoj populaciji.

U decembru 2019. godine u Vuhanu, provinciji Hubei u Kini, kao uzročnik virusne pneumonije identifikovan je novi korona virus (SARS-CoV-2), koji pripada istoj podgrupi virusa kao i virusi: MERS-CoV i SARS-CoV. Bolest uzrokovana SARS-CoV-2 naziva se COVID-19. Korona virusi su RNK virusi sa omotačem. Postoje dve pretpostavke nastanka virusa SARS-CoV-2: prva, da je potekao iz životinjskog izvora i da je prenošenje bolesti ostvareno kontaktom između ljudi i druga da je virus veštačkog porekla, nastao u laboratoriji (WHO, 2020; Balasubramanian i dr., 2021; Lukinović, Jovanović, 2020). Svetska zdravstvena organizacija (SZO) proglasila je pandemiju, izazvanu COVID-19, 14.03.2020. godine, koja još uvek traje.

Zdravstvena, socijalna i ekonomska kriza zatekla je većinu država na različitom nivou pripremljenosti za funkcionisanje u vanrednim novonastalim okolnostima. Kao odgovor na krizu mnoge države su u početku pandemije preduzimale određene restriktivne mere u cilju prevencije, kontrolisanja i njenog zaustavljanja. Mere su varirale od: zatvaranja granica, restrikcija međudržavnog saobraćaja, ogranlčavanja rada pojedinih objekata, do karantina i policijskog časa.

Istraživanja su pokazala: da je za godinu dana, COVID-19 stigao u gotovo sve delove planete, da je virusom zaraženo više od 67,7 miliona ljudi širom sveta, da je broj preminulih prešao 1,5 milion, da posle godinu dana borbe protiv strašne bolesti $u$ čitavom svetu broj novozaraženih raste, da mnoge države ponovo uvode stroge mere zaštite, kao i da je globalno širenje pandemije, pored katastrofalnih posledica po zdravlje ljudi i povećane smrtnosti, izazvalo globalnu ekonomsku recesiju i šok za koji svet nije bio spreman (Zapadni Balkan, 2020; Radić i dr., 2020).

Vakcinacija predstavlja aktivnu imunizaciju, gde se namernim ubacivanjem oslabljenih uzročnika pojedinih bolesti ili određenih njihovih delova, u organizam, izaziva reakcija imunog sistema - stvaraju se antitela koja su specifična za tog uzročnika, odnosno bolest koju izaziva. Kada se jednom stvore, antitela postaju dugotrajna „odbrambena snaga“ koja je spremna da se aktivira i efikasno brani organizam onda kada on bude napadnut od strane bakterije ili virusa koji izaziva bolest. Vakcinacija je jednostavan, bezbedan, efikasan, najbolji način da se čovečanstvo zaštiti od zaraznih bolesti, pa i od COVID-19.
Vakcine su se pojavile i ljudi se masovno vakcinišu, ali bolest i dalje traje. Postoje brojne vakcine, u Velikoj Britaniji, Evropi i Americi su odobrene Fajzer (Pfizer-BioNTech), Moderna (iRNK vakcine) i Oksford AstraZeneca (vektorske vakcine), u Kini razvili su vakcine Sinovak, Kansino i Sinopharm (inaktivisana vakcina), ruski istraživački centar Gamaleja je napravio Sputnjik V. Vakcine su napravljene na potpuno različite načine i one uče naše telo da se bori protiv zaraze. Poslednjih nedelja širom sveta pojavljuju se novi sojevi virusa (Biała i dr., 2021; COVID-19 vakcine u Srbiji, 2021; Харченко, 2020).

Prvi slučaj COVID-19 u Republici Srbiji je registrovan 06.03.2020. godine. Početak borbe u Srbiji, protiv strašne pošasti, traje od 16.03.2020. godine, kada je proglašeno vanredno stanje i uveden policijski čas. Epidemija izazvana COVID-19 u Srbiji je proglašena 20.03.2020. godine. U periodu 1620.03.2020. u Srbiji su donete brojne mere: zabranjene su đačke ekskurzije u inostranstvo, zabranjen je ulaz za strane državljane, obustavljen je putnički avio saobraćaj, zabranjen je izvoz osnovnih namirnica, vršeno je prvo testiranje za nastavu od kuće i prešlo se na on line nastavu, otkazani su letovi i preduzete su vanredne mere. $U$ tom periodu $u$ Klinički centar su stigli prvi respiratori, a Srbija je počela da aplaudira zdravstvu (Lazić i dr., 2020; Službeni glasnik RS, br. 25/20, 27/20, 29/20, 30/20, 35/20, 37/20, 39/20, 47/20, 54/20, 55/20).

Prva pomoć za borbu protiv virusa u Srbiju je stigla 16.03.2020. iz Kine, 20.03.2020. iz Norveške, a dan kasnije i iz EU. Od 20.03.2020. su formirani krizni štabovi za pomoć ljudima koji su se zatekli u inostranstvu, krenuli su avioni po građane Srbije, odlučeno je da će preko granice moći samo kamioni, obustavljen je gradski i javni prevoz, rad kafića, restorana i tržnih centara. Tog 20.03.2020. Srbija je imala i prvu žrtvu strašnog virusa. Dva dana kasnije u Srbiju su stigli stručnjaci i oprema iz Kine. To su bili počeci naše borbe protiv COVID-19. Kako se COVID-19 širio po svetu, tako su i problemi sa kojima se suočavala globalna ekonomija postajali sve veći. Ono što je evidentno je da je prvi udar virusa šokirao privredu u celom svetu (Pandemija Covid-19 u Srbiji - Vikipedija).

U Srbiji su pitanja solidarnosti, zdravlja nacije, zaštite životne sredine, globalizacije, resursne zavisnosti i ustaljeni načini proizvodnje postali predmet preispitivanja.

Da bi se sprečili širenje COVID-19 i posledice koje pandemija ima na ekonomiju mnoge zemlje, a i naša, donele su vanredne mere kojima su regulisale 
uvoz, odnosno, izvoz proizvoda značajnih za zaštitu zdravlja stanovništva i snabdevanje tržišta. Da bi zaštitila tržište Republika Srbija je donela mere tako što je zabranila izvoz određenih proizvoda (osnovnih životnih namirnica i sredstava za higijenu) od značaja za snabdevanje stanovništva. Radi olakšanja stavljanja na tržište neophodnih medicinskih sredstava i lekova, u vreme trajanja epidemije COVID-19 u Srbiji je ukinuta primena tehničkih uslova i standarda, pod uslovom da proizvođač, odnosno distributer Agenciji za lekove i medicinska sredstva dostavi dokumentaciju propisanu Uredbom. Zbog potrebe za praćenjem prekograničnog prometa robe, ali i zbog poštovanja mera ograničenja kretanja i racionalnog korišćenja kadrovskih kapaciteta Uprave carina, određeni su granični prelazi i unutrašnje organizacione jedinice ove uprave koji će u vreme važenja vanrednog stanja obavljati poslove carinjenja (Službeni glasnik RS, br. 28/20, 32/20, 33/ 20, 39/20, 41/20, 43/20, 47/20).

U Srbiji je pre četiri meseca otpočela masovna vakcinacija stanovništva, najpre zdravstvenih i prosvetnih radnika, a zatim i najstarijih stanovnika (korisnika domova za stare). Srbija je jedna od retkih zemalja gde se svaki stanovnik može odlučiti za jednu od četiri ponuđene vakcine: Fajzer, Oksford AstraZeneca, Sinopharm i Sputnjik V. Po podacima Srbija je na drugom mestu po broju vakcinisanih stanovnika na milion. Srbija je pomogla i susedima, najpre donacijom sanitetskog materijala (maski, rukavica) i respiratora, a zatim i doniranjem vakcina zemljama okruženja. Srbija je otvorila je svoje granice i omogućila vakcinisanje stanovnika iz okruženja (Biała i dr., 2021).

U odbrani organizma od infekcije ključnu ulogu imaju antitela koja sprečavaju da patogen uđe u ćelije domaćina i olakšavaju njegovo uništavanje. Kada se organizam izbori sa infekcijom, određena vrsta antitela ostaje u krvi dugo vremena, kako bi zaštitila organizam od iste infekcije u narednom periodu života. Ovakva antitela imunski sistem proizvodi nakon svake prirodne infekcije i nakon vakcinacije. Serološka testiranja omogućavaju detekciju prisustva antitela na određenu infekciju u krvi ispitivane osobe (Chan i dr., 2021). Istraživanja vezana za ovu problematiku su prva u Srbiji urađena u Institut za primenu nuklearne energije INEP koji je osnovan 1959. godine. Istraživanja su podržana od strane Ministarstva prosvete, nauke i tehnološkog razvoja Republike Srbije. Osim navedenih istraživanja, u INEP-u se sve vreme pandemije vodila i vodi borba za bezbednost, zaštitu i sigurnost stanovništva Srbije od jonizujućeg zračenja.

\section{MATERIJALI I METODE /}

\section{MATERIALS AND METHODS}

Već je rečeno, da je naša zemlja već prvih nedelja pandemije donela vanredne mere kojima je regulisala uvoz i izvoz proizvoda značajnih za zaštitu zdravlja stanovništva i snabdevanje tržišta i da su samo određeni granični prelazi u vreme važenja vanrednog stanja obavljali poslove carinjenja.

Sve što je ulazilo u našu zemlju, a i bilo namenjeno izvozu, moralo je zbog bezbednosti i zaštite stanovništva biti kontrolisano na radioaktivnost, jer radionuklidi, prirodni i proizvedeni, procesima migracije, akumulacije i eliminacije, dospevaju u zemljište i vodu, a preko njih u namirnice biljnog i životinjskog porekla i doprinose ukupnom radijacionom opterećenju stanovništva. U INEP-u je sve vreme pandemije praćen sadržaj prirodnih i veštački proizvedenih radionuklida u uzorcima uzorkovanim od strane granične fitosanitarne ili veterinarske inspekcije ili firmi koje se bave uvozom i izvozom.

INEP je ovlašćeno pravno lice za poslove merenja sadržaja radionuklida u vodi za piće, životnim namirnicama, stočnoj hrani, veštačkim đubrivima, lekovima, predmetima opšte upotrebe, građevinskom materijalu, rudama, metalnim proizvodima primarnog oblika, mineralnim sirovinama, sekundarnim sirovinama i drugoj robi. Pravilnikom o granici sadržaja radionuklida u vodi za piće, životnim namirnicama, stočnoj hrani, lekovima, predmetima opšte upotrebe, građevinskom materijalu i drugoj robi koja se stavlja u promet regulisane su granice sadržaja radionuklida u njima (Službeni glasnik $\mathrm{RS}$, 36/2018). Za određivanje nivoa aktivnosti u uzorcima korišćena je gamaspektrometrijska metoda, koja omogućava kvalitativno i kvantitativno određivanje prisustva radionuklida u različitim uzorcima biosfere u energetskom opsegu od $30 \mathrm{keV}$ do 30 $\mathrm{MeV}$. Za određivanje nivoa aktivnosti radionuklida korišćen je poluprovodnički germanijumski detektor visoke čistoće $n$ tipa, proizvođača ORTEC AMETEK, USA, sa 8192 kanala, rezolucije 1,65 keV i relativne efikasnosti od $34 \%$ na $1,33 \mathrm{MeV}$ za ${ }^{60} \mathrm{Co}$. Obrada spektra je vršena pomoću softverskog paketa Gamma Vision 32 (IAEA, 1989).

\section{REZULTATI I DISKUSIJA / RESULTS AND DISCUSSION}

Uprkos pandemiji i teškoj situaciji u kojoj se našao ceo svet, naša država je dala veliki doprinos i učinila napor da njeno stanovništvo ne oseti nestašicu robe u prodavnicama i ne oskudeva ni u čemu, što je bio slučaj u mnogim zemljama Evrope (Italija, Francuska...). Ispitivanja rađena u INEP-u govore u prilog navedenog. 
Tabela 1 - Broj analiziranih uzoraka (namirnice, stočna hrana, predmeti opšte upotrebe, veštačko đubrivo i ostalo) od januara do juna u 2018, 2019. i 2020.

Table 1 - Number of analyzed samples (food, animal feed, general purpose items, mineral fertilizers and other) from January to June in 2018, 2019 and 2020

\begin{tabular}{|c|c|c|c|c|c|c|c|}
\hline \multirow{3}{*}{ Mesec } & Godina & Namirnice & $\begin{array}{c}\text { Stočna } \\
\text { hrana }\end{array}$ & $\begin{array}{c}\text { Predmeti } \\
\text { opšte } \\
\text { upotrebe }\end{array}$ & $\begin{array}{c}\text { Veštačko } \\
\text { đubrivo }\end{array}$ & Ostalo & Ukupno \\
\hline \multirow{3}{*}{ Januar } & 2018. & 159 & 2 & 1 & 41 & 21 & 224 \\
\cline { 2 - 8 } & 2019. & 109 & 0 & 0 & 10 & 6 & 125 \\
\cline { 2 - 8 } & 2020. & 150 & 0 & 9 & 6 & 58 & 223 \\
\hline \multirow{3}{*}{ February } & 2018. & 173 & 3 & 1 & 5 & 18 & 200 \\
\cline { 2 - 9 } & 2019. & 85 & 0 & 1 & 6 & 24 & 116 \\
\cline { 2 - 9 } & 2020. & 189 & 1 & 7 & 26 & 64 & 287 \\
\hline \multirow{3}{*}{ Mart } & 2018. & 229 & 2 & 1 & 27 & 18 & 277 \\
\cline { 2 - 8 } & 2019. & 89 & 0 & 3 & 18 & 17 & 127 \\
\cline { 2 - 8 } & 2020. & 226 & 0 & 9 & 35 & 49 & 319 \\
\hline \multirow{3}{*}{ April } & 2018. & 202 & 0 & 5 & 18 & 11 & 236 \\
\cline { 2 - 8 } & 2019. & 112 & 0 & 0 & 18 & 17 & 147 \\
\cline { 2 - 8 } & 2020. & 182 & 2 & 5 & 14 & 62 & 265 \\
\hline \multirow{3}{*}{ Maj } & 2018. & 216 & 3 & 10 & 21 & 29 & 279 \\
\cline { 2 - 8 } & 2019. & 254 & 0 & 0 & 5 & 25 & 284 \\
\cline { 2 - 8 } & 2020. & 229 & 1 & 8 & 25 & 48 & 311 \\
\hline \multirow{3}{*}{ Jun } & 2018. & 192 & 1 & 0 & 26 & 6 & 225 \\
\cline { 2 - 8 } & 2019. & 193 & 0 & 1 & 4 & 35 & 233 \\
\cline { 2 - 8 } & 2020. & 323 & 0 & 13 & 14 & 66 & 416 \\
\hline
\end{tabular}

U tabeli 1 prikazan je broj ispitanih uzoraka (namirnice, stočna hrana, predmeti opšte upotrebe, veštačko đubrivo i ostalo) od januara do juna 20182020. godine urađenih u INEP-u. Analizom podataka prikazanih u tabeli 1 zaključuje se da je u prva tri meseca 2020. godine ispitano 829 uzorka, što je 2,3 puta više u odnosu na isti period 2019. godine i 1,2 puta više u odnosu na 2018. godinu. Broj ispitanih uzoraka namirnica 2020. i 2018. godine je približno isti, a približno 2 puta veći u odnosu na 2019. godinu. Iz tabele 1 evidentan je porast broja analiziranih uzoraka u martu 2020. godine: 2,5 puta više u odnosu na 2019. godinu i 1,2 puta u odnosu na 2018. godinu.

Analizom podataka prikazanih u tabeli 1 zaključuje se da je u drugom tromesečju 2020. godine ispitano 992 uzorka, što je 1,3 puta više u odnosu na isti period 2019. godine i 1,5 puta više u odnosu na 2018. godinu. Takođe, iz tabele 1 evidentan je veliki broj ispitanih uzoraka u junu 2020. godine (416), kada se Srbija otvorila i pokušala da vrati u život kao pre pandemije (kraj prvog pika epidemije).
Broj ispitanih uzoraka namirnica (1821) u prvih šest meseci 2020. godine je 1,8 odnosno 1,3 puta više u odnosu na 2019. odnosno 2018. godinu. Ukupan broj ispitanih uzoraka i broj ispitanih uzoraka namirnica u martu i maju 2020. godine je bio približno isti.

Analizom podataka prikazanih $\mathrm{u}$ tabeli 2 zaključuje se da je u drugoj polovini 2020. godine analiziran 1629 uzorak, što je 0,7 puta manje u odnosu za isti period 2019. godine; 1,2 puta više $u$ odnosu na 2018. godinu i 1,1 put manje u odnosu na prvu polovinu 2020. godine, što govori da je tržište Srbije bilo stabilno i da za dodatni uvoz nije bilo potrebe. Najviše ispitanih uzoraka u drugoj polovini 2020. godine je bilo u avgustu i oktobru (319).

Analizom podataka koji su prikazani u tabeli 3 najviše je uvezeno, odnosno, izveZeno u 2019. i 2020. godini, brašna i žita; voća i povrća, čokoladnih proizvoda i krem proizvoda. 
Tabela 2 - Broj analiziranih uzoraka (namirnice, stočna hrana, predmeti opšte upotrebe, veštačko đubrivo i ostalo) od jula do decembra u 2018, 2019. i 2020.

Table 2 - Number of analyzed samples (food, animal feed, general purpose items, mineral fertilizers and other) from July to December in 2018, 2019 and 2020

\begin{tabular}{|c|c|c|c|c|c|c|c|}
\hline Mesec & Godina & Namirnice & $\begin{array}{l}\text { Stočna } \\
\text { hrana }\end{array}$ & $\begin{array}{l}\text { Predmeti } \\
\text { opšte } \\
\text { upotrebe }\end{array}$ & $\begin{array}{c}\text { Veštačko } \\
\text { đubrivo }\end{array}$ & Ostalo & Ukupno \\
\hline \multirow{3}{*}{ Jul } & 2018. & 218 & 2 & 0 & 5 & 17 & 242 \\
\hline & 2019. & 269 & 0 & 1 & 21 & 31 & 322 \\
\hline & 2020. & 177 & 1 & 16 & 7 & 35 & 236 \\
\hline \multirow{3}{*}{ Avgust } & 2018. & 164 & 2 & 0 & 23 & 11 & 200 \\
\hline & 2019. & 331 & 2 & 0 & 18 & 31 & 382 \\
\hline & 2020. & 231 & 0 & 12 & 25 & 51 & 319 \\
\hline \multirow{3}{*}{ Septembar } & 2018. & 235 & 1 & 2 & 4 & 12 & 254 \\
\hline & 2019. & 329 & 0 & 7 & 3 & 35 & 374 \\
\hline & 2020. & 161 & 0 & 6 & 13 & 36 & 216 \\
\hline \multirow{3}{*}{ Oktobar } & 2018. & 235 & 1 & 2 & 4 & 12 & 254 \\
\hline & 2019. & 356 & 1 & 2 & 4 & 26 & 389 \\
\hline & 2020. & 242 & 0 & 4 & 17 & 56 & 319 \\
\hline \multirow{3}{*}{ Novembar } & 2018. & 214 & 0 & 0 & 11 & 7 & 232 \\
\hline & 2019. & 358 & 2 & 5 & 3 & 17 & 384 \\
\hline & 2020. & 195 & 1 & 1 & 14 & 69 & 280 \\
\hline \multirow{3}{*}{ Decembar } & 2018. & 181 & 1 & 0 & 11 & 27 & 220 \\
\hline & 2019. & 349 & 0 & 9 & 5 & 13 & 377 \\
\hline & 2020. & 167 & 1 & 12 & 14 & 65 & 259 \\
\hline
\end{tabular}

Tabela 3 - Broj analiziranih namirnica iz uvoza u 2019. i 2020.

Table 3 - Number of analyzed food imported in 2019 and 2020

\begin{tabular}{|c|c|c|c|c|c|}
\hline Vrsta namirnice & $\mathbf{2 0 1 9 .}$ & $\mathbf{2 0 2 0 .}$ & Vrsta namirnice & $\mathbf{2 0 1 9 .}$ & $\mathbf{2 0 2 0 .}$ \\
\hline Žito, brašno & 348 & 407 & Čaj & 33 & 23 \\
\hline Hleb, peciva i sl. & 3 & 34 & $\begin{array}{c}\text { Čokoladni proizvodi, } \\
\text { krem proizvodi }\end{array}$ & 81 & 68 \\
\hline Testenine & 19 & 11 & Bombonski proizvodi & 7 & 22 \\
\hline Šećer & 1 & 0 & $\begin{array}{c}\text { Keks, žita za doručak, } \\
\text { snek, suvo pečeni }\end{array}$ & 16 & 27 \\
\hline Ulje, margarin & 5 & 2 & $\begin{array}{c}\text { Dodatak jelima, supe, } \\
\text { sosovi }\end{array}$ & 1 & 9 \\
\hline Sveže voće i povrće & 11 & 20 & Začini & 4 & 0 \\
\hline Voćni sokovi & 3 & 16 & $\begin{array}{c}\text { Ostali prehrambeni } \\
\text { proizv. biljnog porekla }\end{array}$ & 15 & 10 \\
\hline Ostali proizvodi od voća & 21 & 68 & $\begin{array}{c}\text { Osvežavajuća } \\
\text { bezalkoholna pića }\end{array}$ & 136 & 4 \\
\hline Proizvodi od povrća & 6 & 5 & Žestoka alkoholna pića & 1 & 2 \\
\hline $\begin{array}{c}\text { Voće i povrće } \\
\text { (iz hladnjača) }\end{array}$ & 178 & 213 & Ostalo & 645 & 453 \\
\hline Kafa & 1 & 2 & & & \\
\hline
\end{tabular}




\section{ZAKLJUČAK / CONCLUSION}

Prvi stanovnik Srbije oboleo od COVID-19 evidentiran je 06.03.2020. godine. Vanredno stanje u Srbiji je proglašeno 16.03.2020. godine. Epidemija COVID-19 je proglašena 20.03.2020. godine. Stanovništvo je bilo u panici od epidemije, nestanka osnovnih životnih namirnica (brašno, šećer, ulje, konzerve, kvasac) i sredstava za higijenu (sapun, toalet papir, deterdžent...) u prodavnicama. Da bi sprečila paniku država je omogućila uvoz i izvoz robe iz Srbije. Povećan broj analiziranih uzoraka iz uvoza i izvoza zabeležen je 2020. godine u odnosu na 2018. i 2019. godinu. Najviše je uvezeno i izvezeno: brašna i žita, voća i povrća, čokoladnih i krem proizvoda.

U INEP-u je u prvoj polovini 2020. godine analizirano $57 \%$ više uzoraka u odnosu na 2019 . godinu. Rezultati govore u prilog da je Republika Srbija učinila napor u 2020. godini da stanovništvo ne oseti nestašicu robe u prodavnicama, kao što se desilo u nekim mnogo razvijenijim zemljama Evrope. Zaključuje se da je Republika Srbija u stanju da se nosi s ekonomskim posledicama korona-krize.

\section{Zahvalnica / Acknowledgments}

Istraživanja predstavljena u ovom radu su urađena uz finansijsku podršku Ministarstva prosvete, nauke i tehnološkog razvoja Republike Srbije, u okviru finansiranja naučno istraživačkog rada na Univerzitetu u Beogradu, Institut za primenu nuklearne energije-INEP, prema ugovoru sa evidencionim brojem 451-03-09/2021-14/200019.

\section{LITERATURA / REFERENCES}

[1] Balasubramanian, G., Thangarasu, R., Mathiyazhakan, M., Natesan, M., Jaganathasamy, N., Aridoss, S., Arumugame, E., Yashpal Singh, M. (2021). Epidemiology and pathobiology of SARS-CoV-2 (COVID-19) in comparison with SARS, MERS: An updated overview of current knowledge and future perspectives. Clinical Epidemiology and Global Health.10, 100694.

[2] Biała, M., Lelonek, E., Knysz, B. (2021). COVID-19 vaccine candidates: A review Szczepionki przeciwko COVID-19 - aktualny stan wiedzy. Postepy Hig Med Dosw (online). $75,58-63$.

[3] Chan, C.W., Shahul, S., Coleman, C., Tešić, V., Parker, K., Yeo, K.T.J. (2021). Evaluation of the Truvian Easy Check COVID-19 IgM/lgG Lateral Flow Device for Rapid Anti-SARS-CoV2 Antibody Detection. Am J Clin Patho. 155, 286-295.

[4] Ekonomski i socijalni uticaj COVID-19. Izgled za Zapadni Ballkan, Zapadni Balkan. Redovni ekonomski izvještaj (2020). br.17 (www.worldbank.org/eca/wbrer).

[5] Харченко, Е.П. (2020). Вакцины против Covid-19: сравнительная оценка рисков аденовирусных векторов. Эпидемиология $u$ Вакцинопрофрилактика. 19 (5), 4-17.

[6] IAEA, (1989). Measurement of Radionuclides in Food and Environment. A guidebook, Technical Report Series. No. 295, Vienna.

[7] Katedra za mikrobiologiju i imunologiju, Univerzitet u Beogradu - Farmaceutski fakultet u saradnji sa Agencijom za lekove i medicinska sredstva Srbije, Accessed 10.05.2021, https://www.farmkom.rs/pdf/slider/Brosura\%20 vakcina_final1322123797.pdf

[8] Lazić, N., Lazić. V., Kolarić, B. (2020). First three months of COVID-19 in Croatia, Slovenia, Serbia and Federation of Bosnia and Herzegovina - comparative assessment of disease control measures. Infektol Glasn. 40(2), 43-49.

[9] Lukinović, M., Jovanović, L. (2020). Uticaj pandemije COVID-19 na životnu sredinu. Ecologica. 27 (99), 376-382.

[10] Odluka o zatvaranju graničnih prelaza. (2020). Službeni glasnik RS. br. 25.

[11] Odluka o zatvaranju graničnih prelaza. (2020). Službeni glasnik RS. br. 27.

[12] Odluka o proglašenju vanrednog stanja. (2020). Službeni glasnik RS. br. 29.

[13] Odluka o obustavi izvođenja nastave u visokoškolskim ustanovama, srednjim i osnovnim školama i redovnog rada ustanova predškolskog vaspitanja i obrazovanja. (2020). Službeni glasnik RS. 30.

[14] Odluka o zatvaranju graničnih prelaza. (2020). Službeni glasnik RS. br. 35.

[15] Odluka o zatvaranju svih graničnih prelaza za ulazak u Republiku Srbiju. (2020). Službeni glasnik RS. br. 37.

[16] Odluka o ograničenju pružanja usluga u oblasti trgovine na malo, koje obuhvataju prodaju robe i vršenje usluga u trgovinskim centrima i lokalima u koje se ulazi iz zatvorenog prostora. (2020). Službeni glasnik RS. br. 39.

[17] Odluka o zatvaranju graničnih prelaza. (2020). Službeni glasnik RS. br. 47.

[18] Odluka o privremenoj zabrani izvoza osnovnih proizvoda bitnih za stanovništvo. (2020). Službeni glasnik RS. br. 54 .

[19] Odluka o zabrani izvoza lekova. (2020). Službeni glasnik RS. br. 32.

[20] Odluka o zabrani izvoza lekova. (2020). Službeni glasnik RS. br. 47. 
[21] Odluka o zabrani izvoza lekova. (2020). Službeni glasnik RS. br. 55.

[22] Odluka o privremenoj zabrani izvoza osnovnih proizvoda bitnih za stanovništvo. (2020). Službeni glasnik RS. br. 28.

[23] Odluka o privremenoj zabrani izvoza osnovnih proizvoda bitnih za stanovništvo. (2020). Službeni glasnik RS. br. 32.

[24] Odluka o privremenoj zabrani izvoza osnovnih proizvoda bitnih za stanovništvo. (2020). Službeni glasnik RS. br. 33.

[25] Odluka o privremenoj zabrani izvoza osnovnih proizvoda bitnih za stanovništvo. (2020). Službeni glasnik RS. br. 41.

[26] Odluka o privremenoj zabrani izvoza osnovnih proizvoda bitnih za stanovništvo. (2020). Službeni glasnik RS. br. 43.

[27] Пандемија ковида 19 у Србији - Vikipedija, https://sr.wikipedia.org/wiki/Пандемија_ковида _19_у_Србији, Accessed 10.05.2021.
[28] Pravilnik o granicama sadržaja radionuklida u vodi za piće, životnim namirnicama, stočnoj hrani, lekovima, predmetima opšte upotrebe, građevinskom materijalu i drugoj robi koja se stavlja u promet. (2018). Službeni glasnik RS. br. 36.

[29] Radić, V., Radić, N., Ravić, N. (2020). Uticaj pandemije korona virusa na ciljeve održivog razvoja i ekonomiju. Ecologica, 27 (99), 366374.

[30] Uredba o posebnim tehničkim zahtevima, standardima i primeni medicinskih sredstava za vreme vanrednog stanja nastalog usled bolesti COVID19 izazvane virusom SARS-CoV-2 (2020). Službeni glasnik RS. br. 41.

[31] WHO. (2020). Clinical management of severe acute respiratory infection (SARI) when COVID-19 disease is suspected. Interim guidance. Accessed 10.05.2021,

https://apps.who.int/iris/handle/10665/331446 